[Transaction ]

\title{
A Mixture Phenomena Expressed in Contemporary Knit Fashion -Focus on Woman Collection from 2000 to 2008-
}

\author{
Moon Hee Park $\cdot$ Youn-Hee Lee ${ }^{\dagger}$ \\ Dept. of Fashion Design, Gangneung-Wonju National University \\ *Dept. of Clothing \& Textiles, Hanyang University
}

Received September 24 2009; Revised November 3, 2009; Accepted November 30, 2009

\author{
현대 니트패션에 나타난 호합현상 \\ -2000년 2008년 여성컬렉션을 중심으로- \\ 박문희 · 이연희* $*^{\dagger}$ \\ 강릉원주대학교 의상디자인과, *한양대학교 의류학과 \\ 접수일(2009년 9월 24일), 수정일(2009년 11월 3일), 게재확정일(2009년 11월 30일)
}

\begin{abstract}
Mixture phenomena are present in the overall culture due to internationalization in a modern society. A unique feel is required in materials due to the increasing demand for knit wear and there is a need for a strategic plan to achieve this. This study analyzed the appearance frequency and expressive characteristics of mixture phenomena based on selected data from collections related to the mixture phenomena trends in modern women's fashion from 2000 to 2008. Among the mixture phenomena, the mixture of the high and low class cultures had the highest frequency of occurrence and was expressed most often since the expansion of design areas was due to vague high and low concepts. The mixture of sexes showed the sharing of knit wear trends between the sexes with the pursuit of functionality. The mixture of styles showed a tendency to increase since the traditional form was transformed into a mixture of typical styles. The mixture of spaces showed a mixture of old and traditional knit wear patterns from Northern Europe and modern elements. The mixture of other materials showed the partial preceding mixture and the decorative materials that existed beyond it. The mixture of functions refers to the used characteristics of the two items. Imagination will grow and increase the possibility of expressions with the mixture of the other areas.
\end{abstract}

Key words: Mixture phenomena, Expression characteristics, Knit fashion; 혼합현상, 표현특성, 니트패션

\section{Introduction}

Contemporary society is showing the mixture phenomena of crossing spatially between different genres and between different cultures over the whole in culture, due to globalization. Even in costumes, several

Corresponding author

E-mail: yiyhee@ hanyang.ac.kr diverse elements are being mixed with traditional stereotypes, thereby creating new designs. Demand for knit wear is growing due to diversification and highquality stitching. As consumers' individuality diversifies, unique textures are being demanded. This is bringing about a desperate need for strategic plans to produce new textures.

The purpose of this study is to offer data that design- 
ers can extensively use to develop creative materials for knit fashion by considering the frequency of appearance and change of expression characteristics that had been seen in knit fashion for contemporary women, as one of the methods of pursuing a plan for the continued production of creative and unique knit wear.

The objectives of this study are as follows. First, this study seeks to select and classify data from collections related to trends in the mixture phenomena that are expressed in contemporary knit fashion for use as basic data for grasping the present status of the mixture phenomena that are expressed in knit fashion. Second, this study analyzes the features of the expression characteristics of mixture phenomena in knit fashion for contemporary women, according to the historical trend of the diversification and upgrading of consumersí desires. The present status of mixed knit wear phenomena is grasped based on the frequency of appearance of the expression characteristics of such phenomena in knit wear. Thus, this study aims to discover the possibility of producing high-valueadded knit wear by developing creative materials.

\section{Literature Review}

\section{Concept and Characteristics on the Mixture Phenomena}

The dictionary meaning of mixture is what is blended and united into one, or when two or more kinds of substances are mixed without resulting in a chemical combination. A mixture is similar to a 'crossover' a 'hybrid' 'hetero-specific mating' 'multi-culture' and 'fusion' but is more inclusive, and can be said to be a concept in a broad sense.

Terms with meanings that are similar to that of a mixture are fusion, hybrid, and crossover. The dictionary meaning of fusion is the combination or harmonization of separate objects, thoughts, or groups (Park, 2005). Hybrid, which is similar in concept to fusion, implies a half-breed or a compound, and means the combination of two mutually different technologies or systems. "Crossover" originated from music and generally refers to the exchange between classical music and popular music (Kim, 1995). As fusion has an inclusive meaning, it may be used in place of all the aforementioned terms. "Crossover" is used, however, in a narrower sense. The tendency of the emergence of mixture phenomena in popular culture is not an exclusively modern development, but has been seen steadily in history. Fashion is said to be observable even in the domain of pure application arts such as painting, sculpture, and music (Kim, 1998). Accordingly, this study aims to classify the expression characteristics of mixture phenomena by considering the mixture phenomenon, that were seen in 20th century art, architecture, and costumes.

There are five types of mixture phenomena in art history: the mixture of heterogeneous materials and genres, the mixture of cultures, the mixture of art and vulgar culture, the mixture of art and science, and the mixture of time and space. The mixture of heterogeneous materials and genres showed its expression characteristics with the introduction of heterogeneous two-to three-dimensional substances, impromptu combinations, object peculiarities, and beauty in disharmony. The mixture of cultures showed its expression characteristics with the compositive mixture of element, style, exotic propensity, place, and time, which were borrowed from other cultures. The mixture of art and vulgar culture was characterized by the recomposition of mass products and of repetitive forms such as commercial art posters and comics, which had been treated as forms of vulgar culture in pop art. The mixture of art and science and the mixture of time and space showed their expression characteristics with the combination of analog and digital features in kinetic art and media art, and with the mixture of substance and visual images from the introduction of scientific technology. The mixture of time and space showed its expression characteristics with the mixture of the past and the present, the rejection of rules, and the pursuit of visual language among the masses (Cho, 2004; Kim, 2006; Yu, 2003).

The mixture phenomena that were expressed in architectural history are classified into the mixture of styles, which was characterized by replacing classic styles with new materials in modern times, and by using them together; the mixture of programs, by the close adhesion, continuity, and disharmony of heter- 
ogeneous programs; the mixture of heterogeneous materials and form, by the continuous overlap of heterogeneous materials and form; the mixture of intertextuality by the analogy, similarity, and ambiguity of the methods of conceptualization or expression of designs in knit fashion and other arts; the mixture of artistry and science; and the mixture of time and space (Jong, 2006; Myung, 2003; Shin, 2003).

As to the expression characteristics of the mixture phenomena that were seen in costume history, they could be classified into the mixture of times, the mixture of spaces, the mixture of high and low class cultures, the mixture of functions, the mixture of sexes, the mixture of materials, and the mixture of styles. The mixture of times expressed the design element or image in the past and future by combining it with a contemporary costume, thereby showing the characteristic of destroying boundaries in time. The mixture of spaces applied orientalism, the ethnic look, and patterns and colors in the East to Western costumes, thereby creating a new image. The mixture of high and low class cultures was characterized by traditionally high class fashion and luxury materials, patterns, and colors on one hand, and by coarse details as the subordinate concept on the other hand. The mixture of sexes was characterized by the composition of style, its neutralization, and the creation of an ambiguous sexual identity that escapes from the traditional consciousness of sex in woman and man. The mixture of materials was characterized by the matching of heterogeneous materials such as vinyl and paper, and by translucency. The mixture of styles was characterized by the coexistence of an item with its contrary silhouette and image in one design. The mixture of functions resulted in a multifunctional outfit that could be changed depending on the climate or the environment (Cho, 2004; Kim, 2008; Kim, 2003; Lee, 2001; Oh, 2000).

As shown in 〈Table 1>, given the synthesis of the expression characteristics of the mixture phenomena that were seen in art history, architectural history, and costume history, the mixture phenomena that were expressed in art history and architectural history did not show a mixture of sexes in each genre. In architectural history, no mixture of high and low class cultures was seen. Through this analysis, the common mixed phenomena among the expression characteristics of the mixture phenomena that were seen in art history, architectural history, and costume history could be integrated and arranged largely into the following seven kinds: the mixture of spaces, the mixture of times, the mixture in high and low class cultures, the mixture of functions, the mixture of materials, the mixture of styles, and the mixture of sexes (Table 1).

\section{Historical Development in Knit Fashion}

In the long history of fashion, the time when knit fashion became fully popular and was developed into fashion in the modern context was the 1920s. Accordingly, this study examined the historical background during this period and the trend in knit fashion at the

Table 1. Expressive characteristics of mixture phenomena in art history, architecture history, and dress history

\begin{tabular}{|c|c|c|c|}
\hline Art History & Architecture History & Dress History & Total Characteristics \\
\hline Mixture of Cultures & \multirow{2}{*}{ Mixture of Time and Space } & Mixture of Spaces & Mixture of Spaces \\
\hline Mixture of Time and Space & & Mixture of Times & Mixture of Times \\
\hline Mixture of Art and Base Culture & & $\begin{array}{c}\text { Mixture of } \\
\text { High } \cdot \text { Low Class Cultures }\end{array}$ & $\begin{array}{c}\text { Mixture of } \\
\text { High } \cdot \text { Low Class Cultures }\end{array}$ \\
\hline Mixture of Art and Science & Mixture of Art and Science & Mixture of Functions & Mixture of Function \\
\hline $\begin{array}{c}\text { Mixture of } \\
\text { Heterogeneous Materials }\end{array}$ & Mixture of Materials & Mixture of Other Materials & Mixture of Other Materials \\
\hline \multirow{4}{*}{ Mixture of Genres } & Mixture of Forms & \multirow{3}{*}{$\begin{array}{c}\text { Mixture of } \\
\text { Typical and Atypical Styles }\end{array}$} & \multirow{3}{*}{ Mixture of Styles } \\
\hline & Mixture of Mutual Texts & & \\
\hline & Mixture of Programs & & \\
\hline & & Mixture of Sexes & Mixture of Sexes \\
\hline
\end{tabular}


time.

In the 1920s, women's wear showed a trend towards virilism, the sporty look, and casualization due to that time having been a period of stability, abundance, and prosperity, as well as due to the popularity of sports after World War I. The mainstream fashion then was the silhouette, which had modern and simple boxy lines. Also, knit wear became the trend in costumes due to the flexibility of the material on Gabrielle Chanel's jersey, its utility, its re-awakening of the sense of beauty, and its ushering in of formal dresses.

In the 1930s, femininity was emphasized by long and slim lines, embroidery, ribbons, and shirring due to the Great Depression, the development of transportation and communication, and the popularization of arts and movies. Knit fashion was mass-produced due to the invention of the hand-knitting machine called Passap in Switzerland and due to the development of man-made fiber (Jeon, 2001).

In the 1940s, ample sweaters, hood styles, and practical clothes were in vogue as the period saw the popularization of knit wear due to the development of the industry of hand knitting machines along with the ruins and shortage of commodities after World War II. In the 1950s, weapons were produced against the background of the Cold War between the U. S. A. and the Soviet Union. As the commercialization of fashion came along with social specialization and the favorable economy, special knit wear brands appeared. Individual products became luxurious and took advantage of feminine beauty and causal property. As interest in knit wear increased due to the ability to markedly express curvaceousness in the body, knit wear came to be considered luxury fashion (Che, 1999).

In the 1960s, diverse knit styles were used for youth fashion against the social background of the women's liberation movement, Congressman Kennedy's idolization, and pop art, and with the advent of contrasting colors, abstract patterns, and bold patterns from the influence of the modern Wearable Art Movement. In the 1970s, as reasonably multi-purpose fashion was emphasized, convenient clothing with a unisex look and a big and boxy style was popularized in various items. In the 1980s, due to economic leeway and the trend towards extravagance, several styles such as masculine clothing, classic clothing, and anti-form clothing became in vogue all at the same time (Che, 1999). In the 1990s, due to the state of confusion leading to the end of the century, diverse themes such as ecology, recycling, and naturalism coexisted. Due to the diversification of stitches and expression styles in knit wear, individualization and small-quantity batch production emerged. Due to the broad introduction of materials and technologies, knit fashion came to be expressed uniquely.

\section{Methods and Scope}

This research spans the previous nine years from 2000 to 2008. The data for this research were collected from 931 pieces of knit fashion clothing for women from designer collections in the world's four leading fashion centers of London, New York, Paris, and Milan (2000: 99 pieces, 2001: 104 pieces, 2002: 65 pieces, 2003: 107 pieces, 2004: 132 pieces, 2005: 62 pieces, 2006: 133 pieces, 2007: 94 pieces, and 2008: 135 pieces). The kinds of knit wear were limited to 3 18 gauges by placing limits on flat knit fashion. The clothing were classified into seven groups that showed the mixture of times, the mixture of spaces, the mixture of high and low class cultures, the mixture of sexes, the mixture of styles, the mixture of materials, and the mixture of functions, which were extracted from literature research (Table 2). As for the analysis of the mixture phenomena, three experts in the knit fashion field and four doctors in the field of clothing science examined the classification standards and the photo materials. They particularly examined the expression characteristics of the mixture phenomena and their frequency of appearance by year and by season.

\section{Expression Characteristics in the Mixture Phenomena Shown in Contemporary Knit Fashion}

\section{Appearance Frequency in the Mixture Phe- nomena}

The appearance frequency in the mixture phenom- 


\section{Table 2. Characteristics of mixture phenomena}

\begin{tabular}{|c|c|c|}
\hline Mixture Phenomena & Ways of Expression & Characteristics \\
\hline Mixture of Time & $\begin{array}{l}\text { Expressed image of original and reaction past ele- } \\
\text { ments to modern clothes. Mixture of millenium ele- } \\
\text { ments and modern elements. }\end{array}$ & $\begin{array}{l}\text { By integrative expressing design elements and images } \\
\text { of past and future in modern dress, broke the bound- } \\
\text { ary of time. }\end{array}$ \\
\hline Mixture of Space & $\begin{array}{l}\text { Application of oriental colors and patterns, wear- } \\
\text { ing ways of oriental dresses and application of tra- } \\
\text { ditional dresses. Meeting of spiritual side of the } \\
\text { Orient and minimalism of the West. }\end{array}$ & $\begin{array}{l}\text { Applied oriental style, traditional style and patterns } \\
\text { and colors of the Orient to Western dressing to } \\
\text { create new images. }\end{array}$ \\
\hline $\begin{array}{c}\text { Mixture of } \\
\text { High·Low Class Culture }\end{array}$ & $\begin{array}{l}\text { Mixture of sportswear, casual clothing and formal } \\
\text { dresses. Mixture of elements of special clothes and } \\
\text { formal dresses. Undergarments becoming outer gar- } \\
\text { ments. Mixed style of vintage elements and for- } \\
\text { mal dresses. }\end{array}$ & $\begin{array}{l}\text { Mixture of characteristics, quality materials, patterns } \\
\text { and colors of traditional high fashion and crude } \\
\text { details of low concepts. }\end{array}$ \\
\hline $\begin{array}{c}\text { Mixture of } \\
\text { Sex in Man and Woman }\end{array}$ & $\begin{array}{l}\text { Women's style that looks like men's clothes, big } \\
\text { look and feminine colors and patterns of men's } \\
\text { clothes. Style for both sexes. }\end{array}$ & $\begin{array}{l}\text { Composition, neutralization and vague sexual iden- } \\
\text { tity against the traditional sexual recognition of } \\
\text { men and women. }\end{array}$ \\
\hline Mixture of Other Material & $\begin{array}{l}\text { Mixture of other materials not used in garments } \\
\text { such as vinyl and paper. Matching of heteroge- } \\
\text { neous materials which are metal or transluscent. }\end{array}$ & Mixture of different materials. \\
\hline Mixture of Style & $\begin{array}{l}\text { Mixture of typical and atypical style. Mixture of } \\
\text { long-with-short style and asymmetrical style. }\end{array}$ & $\begin{array}{l}\text { Items of contrary silhouettes and images co-exists } \\
\text { in one design. }\end{array}$ \\
\hline Mixture of Function & $\begin{array}{l}\text { Double-sided, multi-functional and wearable com- } \\
\text { puter fashion. }\end{array}$ & $\begin{array}{l}\text { Mixture of changeable functions in different cli- } \\
\text { mates and environments. Mixture of digital. }\end{array}$ \\
\hline
\end{tabular}

ena expressed in contemporary knit fashion, the frequency number was indicated to be higher in order of the mixture of high - low class culture, mixture of sex in man woman, mixture of style, mixture of space, mixture of time, mixture of other material, and mixture of function.

Given examining the appearance frequency and a change by year in the mixture phenomena, the mixture of high - low class culture possessed 300 pieces (32.2\%) among 931 pieces in the whole. The mixture of sex in man and woman possessed 263 pieces (28.3\%). It was indicated to in order of the mixture of style with 143 pieces (15.4\%), mixture of space with 106 pieces $(11.3 \%)$, mixture of time with 56 pieces $(6.0 \%)$, mixture of other material with 55 pieces $(5.9 \%)$, and mixture of function with 8 pieces $(0.9 \%)$ (Table 3).

The mixture phenomena in knit fashion showed the highest frequency number in 2004. The mixture of time showed the highest frequency number. This is analyzed to be related to 'influence of feminine look in the 1950s' and to trend of making it felt vintage. The special matter in the appearance frequency by year showed a trend of being swelled the mixture of style until 2008 based on 2006. Also, the mixture of space steeply increased in 2006, and showed the increasing trend until 2008.

By mixture phenomena, the mixture of high · low class culture was being appeared with the highest ratio. This phenomenon was analyzed to be expressed more creatively by expansion in design domain as a boundary gets ambiguous between a concept of higher fashion and a concept of lower fashion in luxury material, elegant pattern, and color. Also, the phenomenon, which is shown highly the mixture of sex in man and woman, can be found its factor as a trend of trying to pursue functionality and convenience and to share ambivalence owing to a change in concept on sex and to borrowing masculine elements such as big look, straight silhouette, and broad pocket to women's costume (Fig. 1).

\section{Expression Characteristics in the Mixture Phenomena}

\section{1) Mixture of Time}

As the mixture of time is the mixture in the past, the present, and future, it can be tried to be divided 
Table 3. Frequency in the mixture phenomena

\begin{tabular}{|c|c|c|c|c|c|c|c|c|c|c|c|c|c|c|c|c|c|c|c|c|}
\hline \multirow{2}{*}{ Mixture Year } & \multicolumn{2}{|c|}{2000} & \multicolumn{2}{|c|}{2001} & \multicolumn{2}{|c|}{2002} & \multicolumn{2}{|c|}{2003} & \multicolumn{2}{|c|}{2004} & \multicolumn{2}{|c|}{2005} & \multicolumn{2}{|c|}{2006} & \multicolumn{2}{|c|}{2007} & \multicolumn{2}{|c|}{2008} & \multicolumn{2}{|c|}{ Total (\%) } \\
\hline & $\mathrm{s} / \mathrm{s}$ & $f / w$ & $\mathrm{~s} / \mathrm{s}$ & $f / w$ & $\mathrm{~s} / \mathrm{s}$ & $f / w$ & $\mathrm{~s} / \mathrm{s}$ & $f / w$ & $\mathrm{~s} / \mathrm{s}$ & $f / w$ & $\mathrm{~s} / \mathrm{s}$ & $f / w$ & $\mathrm{~s} / \mathrm{s}$ & $f / w$ & $\mathrm{~s} / \mathrm{s}$ & $f / w$ & $\mathrm{~s} / \mathrm{s}$ & $\mathrm{f} / \mathrm{w}$ & $\mathrm{s} / \mathrm{s}$ & $f / w$ \\
\hline \multirow{2}{*}{$\begin{array}{c}\text { The Mixture } \\
\text { of Time }\end{array}$} & 0 & 4 & 2 & 1 & 5 & 0 & 0 & 6 & 4 & 13 & 5 & 4 & 1 & 1 & 0 & 3 & 3 & 4 & 20 & 36 \\
\hline & \multicolumn{2}{|c|}{4} & \multicolumn{2}{|c|}{3} & \multicolumn{2}{|c|}{5} & \multicolumn{2}{|c|}{6} & \multicolumn{2}{|c|}{17} & \multicolumn{2}{|c|}{9} & \multicolumn{2}{|c|}{2} & \multicolumn{2}{|c|}{3} & \multicolumn{2}{|c|}{7} & \multicolumn{2}{|c|}{$56(6.0)$} \\
\hline \multirow{2}{*}{$\begin{array}{c}\text { The Mixture } \\
\text { of Space }\end{array}$} & 4 & 7 & 4 & 1 & 1 & 7 & 1 & 3 & 3 & 7 & 4 & 6 & 9 & 14 & 2 & 11 & 7 & 15 & 35 & 71 \\
\hline & \multicolumn{2}{|c|}{11} & \multicolumn{2}{|c|}{5} & \multicolumn{2}{|c|}{8} & \multicolumn{2}{|c|}{4} & \multicolumn{2}{|c|}{10} & \multicolumn{2}{|c|}{10} & \multicolumn{2}{|c|}{23} & & & & & 106 & (11.3) \\
\hline The Mixture & 14 & 19 & 8 & 34 & 10 & 9 & 16 & 27 & 15 & 20 & 5 & 11 & 25 & 21 & 9 & 16 & 15 & 26 & 117 & 183 \\
\hline $\begin{array}{l}\text { of } \mathrm{High} \cdot \text { Low } \\
\text { Culture }\end{array}$ & & 3 & & & & & & 3 & & & & & & & & & & & 300 & $(32.2)$ \\
\hline The Mixture & 17 & 22 & 9 & 32 & 8 & 13 & 14 & 12 & 11 & 27 & 3 & 13 & 22 & 17 & 3 & 15 & 5 & 20 & 92 & 171 \\
\hline $\begin{array}{c}\text { of Sex in Man } \\
\text { and Woman }\end{array}$ & & 9 & & & & & & 6 & & & & & & & & & & & 263 & (28.3) \\
\hline The Mixture & 2 & 3 & 2 & 2 & 3 & 4 & 1 & 19 & 14 & 11 & 5 & 4 & 5 & 13 & 10 & 13 & 7 & 25 & 49 & 94 \\
\hline of Style & & ; & & & & & & 0 & & & & & & & & & & & 143 & (15.4) \\
\hline The Mixture & 1 & 6 & 1 & 8 & 2 & 1 & 6 & 1 & 2 & 1 & 1 & 1 & 1 & 3 & 7 & 5 & 4 & 4 & 25 & 30 \\
\hline $\begin{array}{l}\text { of Other } \\
\text { Material }\end{array}$ & & & & & & & & 7 & & & & & & & & & & & & $(5.9)$ \\
\hline The Mixture & 0 & 0 & 0 & 0 & 0 & 2 & 1 & 0 & 1 & 3 & 0 & 0 & 0 & 1 & 0 & 0 & 0 & 0 & 2 & 6 \\
\hline of Function & & 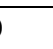 & & & & & & 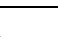 & & & & ) & & & & & & & & $(0.9)$ \\
\hline Total & 38 & 61 & 26 & 78 & 29 & 36 & 39 & 68 & 50 & 82 & 23 & 39 & 63 & 70 & 31 & 63 & 41 & 94 & 340 & 591 \\
\hline Iotal (\%) & 99( & $0.6)$ & 104 & 1.2) & 65( & 6.9) & 107 & 11.5) & 132 & 4.5) & 62( & 6.6) & 133 & 4.1) & 94( & $0.1)$ & 135 & 4.3) & 931 & (100) \\
\hline
\end{tabular}

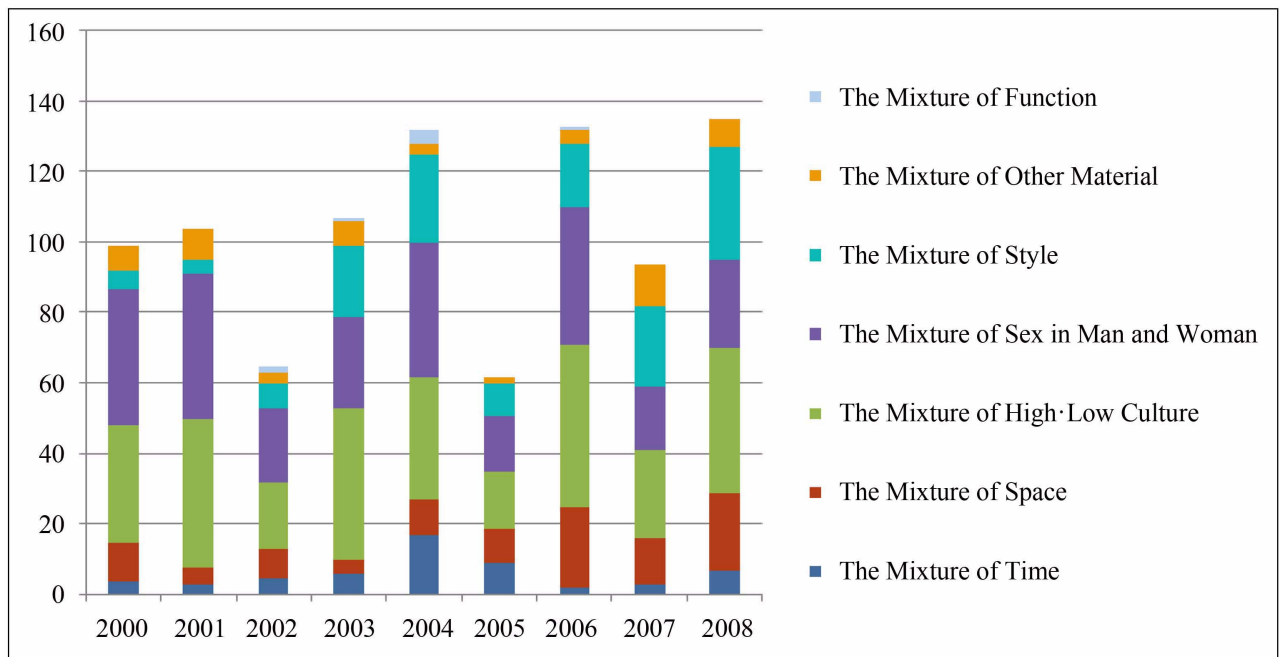

Fig. 1. Appearance frequency in the mixture phenomena.

into the mixture of the past and the mixture of future as 'mixture of period' (Cho, 2002) which is blended and shown each characteristic. As the mixture of the primitive past is what is often shown in primitive men's creature, it is showing image of being expressed by accepting natural material and primitive material and by using modern materials in elements such as patterns or accessories. Also, the mixture of the retro past integrates the historical situation and sensation at that time with the present, thereby having characteristic of creating new significance and value in line with modern sensitivity (Kim, 2007). 
In the mixture of time that was expressed in a case of modern knit fashion, the mixture of the past was expressed silhouette or detailed ornament through modern analysis, suitably for the today's characteristic of being intermediate and combinative, rather than literally imitating original image. The mixture of the past in the primitive and retro trend was expressed as a result of re-creation through modern re-analysis by reconstructing a form or detailed ornament into luxury material or item, rather than the original spirit. In a case of modern knit fashion, the mixture of future was developing the functional sportism practically, lightly, conveniently, and used diversely techno materials mainly in a simple, thereby having been expressed with the transitional and future-oriented trend.

\section{2) Mixture of Space}

As a result of analyzing the mixture of space, it could be divided into the mixture of China's traditional costume, which is typical in Orientalism, the mixture of Japan's traditional costume, and the mixture of traditional knit pattern in other Asia and Northern Europe.

Silhouette, which was shown as characteristic in the mixture of China's traditional costume, expressed sensitivity of China's traditional clothing with structural line based on pattern style in the West. The expression characteristic was shown with the mixture in the partial application of trim or collar shape and the modern image. In pattern and detail, its characteristic was shown with the mixed element of utilizing dragon, butterfly, lotus flower, and Chinese character in Chinese style as motif in partial design.

Given examining characteristics in the mixture of Japan's traditional costume, the silhouette was mixed the asymmetrically front part in Kimono, breastedness, simple line, and partially straight cutting method in addition to composition in a Western-styled form. Pattern and detail were shown its expression characteristic with the application of printing elaborate crane, and flower pattern peculiar to Japan, and with the mixture of graceful and moderate color in achromatic-color system, meditation, religious, temperance, center on nature-friendly flat cutting, and Zen Style in minimal silhouette.
The expression characteristic in Northern Europe and other regions was shown with the transformation in Northern Europe's folk pattern and traditional Aran pattern into simplification and a change in vertical and horizontal band, and with the mixture of practical silhouette and modern silhouette. The mixture of other regions was shown the characteristic with mixing harem pants and turban, which get tightened in more going down, with the Western costume.

\section{3) Mixture of High Low Class Culture}

A concept in the higher and lower classes in fashion had the bisectionally antagonistic relationship of symbolizing an individual's social position. While the characteristic in the high class fashion was the design that is composed of luxury material, elegant pattern and color, the low class fashion was composed of the design in coarse detail and cheap material. The mixture of high - low class culture, which was expressed in contemporary knit fashion, could be classified into the mixture of Grungy element and high fashion, mixture of kidult element and high fashion, mixture of underwear and high fashion, and mixture of working clothes and high fashion. The mixture of grungy element and high fashion was shown with the expression characteristic in the mixture of heterogeneous pattern, and in tear, slit without the end treatment due to fraying the end strand in the knit fashion with basic stitch, patch work, fringing and tone-down gray, use of khaki and blue color, and match in opposite color. The mixture of kidult element and high fashion was shown with characteristic of expressing humor and fun with graffiti, expression like character and cartoon, and fairy-tale fantasy through the exaggerated trifling article. The mixture of underwear and high fashion was shown the expression characteristic with the emphasis on underwear line like volume up, or with the mixture of details such as pants in diverse lengths, mini skirt, underwear lace, and ribbon.

Also, the mixture of element of working clothes was shown the characteristic of enriching design by utilizing zipper decoration, banding, tape, and buckle decoration in the ornament aspect rather than functional aspect. 


\section{4) Mixture of Sex in Man and Woman}

The mixture of sex in man and woman shows the trend of trying to share both sexes by being mixed the functionality in men's wear, decoration in women's wear image, borrowing in color, the functionality in men's wear image for women's wear due to a change in a concept of traditional sex, and shown the general characteristic due to the consolidated phenomenon in sex. Given seeing a case that was shown in contemporary knit fashion, the silhouette was neutral due to straight silhouette in men's suit and to borrowing of the broad shoulder line. Also, the feminine look was emphasized further with the fitted line that is revealed woman's curve. The expression characteristics was shown with the use of achromatic color and brownseries color, and the borrowing of hat and necktie.

\section{5) Mixture of Style}

The mixture of style in a case, which was shown in contemporary knit fashion, was shown the expression characteristic with the mixture of the fixed form and non-fixed form and the mixture of item in mutually difference image. In silhouette, there were extension and contraction in partial size, exaggeration in ratio or width, strengthening and shortening. In the mixture of item in mutually different image, there were the mixture of tradition and innovation, match of sporty image, and mixture of mutually opposite image in the sensual aspect such as item in diverse image. In the use, there was match of clothes in completely different styles. Thus, the characteristic was shown that creates new form and image.

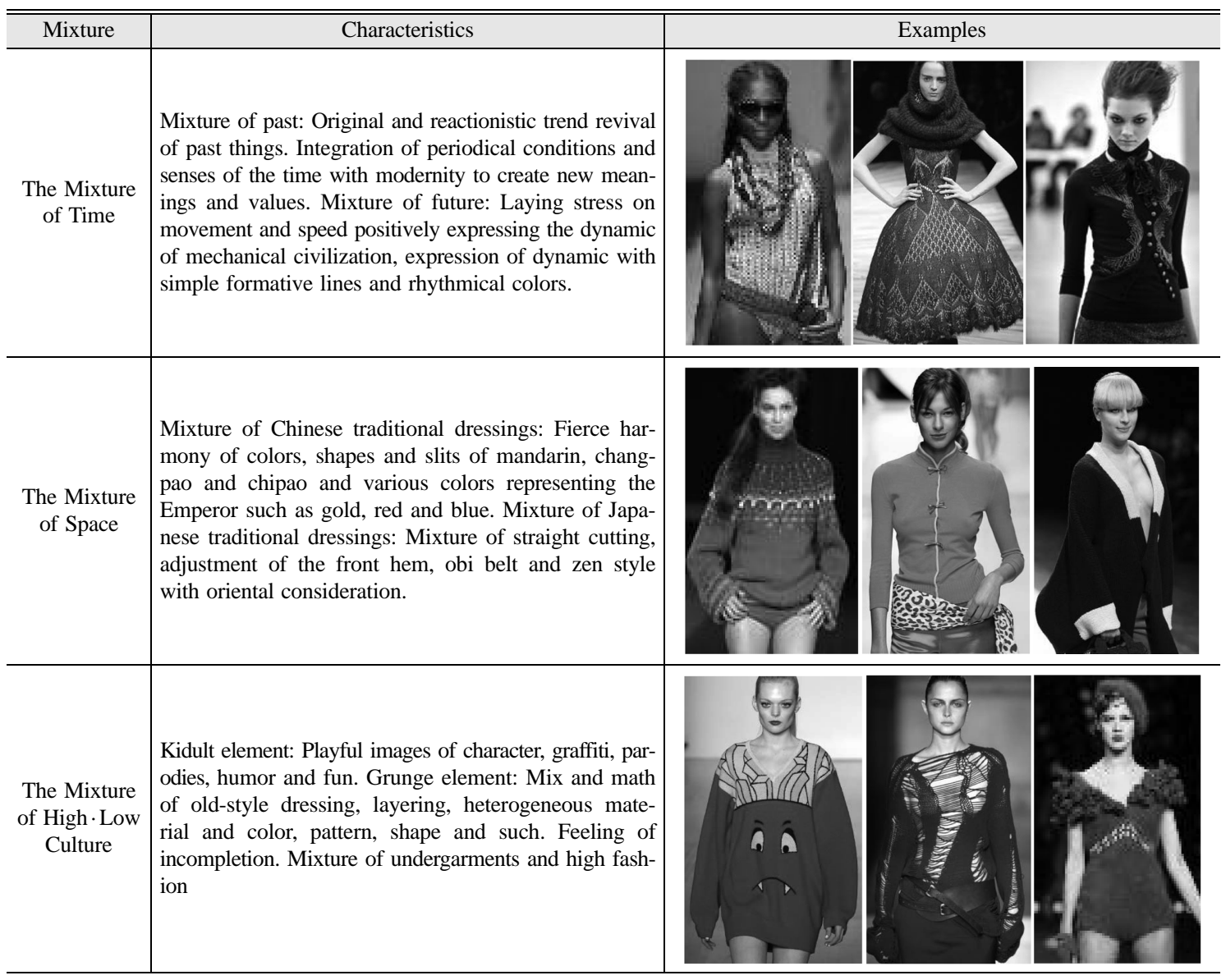

Fig. 2. Characteristics in the mixture phenomena in knit fashion. 


\begin{tabular}{|c|c|c|}
\hline Mixture & Characteristics & Examples \\
\hline $\begin{array}{l}\text { The Mixture } \\
\text { of Sex in Man } \\
\text { and Woman }\end{array}$ & $\begin{array}{l}\text { Trend of sharing both sexes and phenomenon of mixed } \\
\text { existence of sexes: With the change of traditional sex } \\
\text { concepts, feminine decorations and colors were added } \\
\text { to functions of men's clothes and created fitted and } \\
\text { princess silhouette for men. }\end{array}$ & \\
\hline $\begin{array}{c}\text { The Mixture } \\
\text { of Style }\end{array}$ & $\begin{array}{l}\text { Mixture of typical and atypical styles: Omitted basic } \\
\text { forms and basic lines with basic silhouettes and asym- } \\
\text { metrical and nonformative shapes. Mixture of items of } \\
\text { different images: Mixed items of different images to } \\
\text { create fashion of new forms and images. }\end{array}$ & \\
\hline $\begin{array}{l}\text { The Mixture } \\
\text { of Other } \\
\text { Material }\end{array}$ & $\begin{array}{l}\text { Phenomena of using materials which seem to be inap- } \\
\text { propriate. Used all materials including metal, vinyl, } \\
\text { paper, glass fiber, fluorescent fiber and double texture } \\
\text { with hologram effect. }\end{array}$ & \\
\hline $\begin{array}{l}\text { The Mixture } \\
\text { of Function }\end{array}$ & $\begin{array}{l}\text { Double sided multi-functional clothing to meet changes } \\
\text { of multi-functions, modular styles and environment im- } \\
\text { mediately. }\end{array}$ & \\
\hline
\end{tabular}

Fig. 2. Continued.

\section{6) Mixture of Other Material}

The mixture of other material, which was shown in contemporary knit fashion, was utilized the decorative materials such as leather, transparent chiffon, and fur, the partial mixture of surpassing range of use in addition to the originally functional use, the metallic material and the plastic material as heterogenous materials.

\section{7) Mixture of Function}

The mixture of function was shown the expression characteristic in which over two items become one item according to situation and coordination, thereby being available even for a change in silhouette, and can be utilized as the use of two items (Fig. 2). 


\section{Summary and Conclusions}

The purpose of this study was to clarify the expression characteristics in the mixture phenomena, which were shown in contemporary knit fashion, with paying attention to the recent trend that the mixture is markedly shown according to social \& cultural environment.

First of all, it historically considered a concept of mixture and the characteristics in the mixture phenomena that were shown in art history, architecture history, and costume history. The frame in the characteristics of mixture was arranged by analyzing the expression characteristics in the mixture phenomena through a preceding research. Based on this, it analyzed the expression characteristics, the appearance frequency, and a change in the mixed phenomena, which were shown in contemporary knit fashion, with having photo materials in women's flat knit shown in the world's 4 fashion shows in London, Paris, Milan, and New York, from 2000 to 2008.

The following are the conclusions that were obtained through the results of this study. As a result of examining the appearance frequency in the mixed phenomena expressed in contemporary knit fashion, the frequency number was indicated to be higher in order of the mixture of high - low class culture, mixture of sex in man-woman, mixture of style, mixture of space, mixture of time, mixture of other material, and mixture of function. The mixed phenomena in knit fashion showed the highest frequency number in 2004. The mixture of time showed the highest frequency number related to influence of feminine look in the 1950's and to trend of making it felt vintage. The special matter in the appearance frequency by year showed a trend of being swelled the mixture of style until 2008 based on 2006. The highest ratio, mixture of high - low class, was analyzed to be expressed more as a boundary gets ambiguous beyond the concept of higher fashion and the lower fashion. And also, mixture of sex in man and woman can be found its factor as a trend of trying to share ambivalence owing to a change in concept on sex.

Examining the expression characteristics in the mixture phenomena in contemporary knit fashion, the mixture of high - low class culture was shown the most due to being expanded the design domain as a boundary gets ambiguous between a concept of high - class fashion and a sub-concept in luxury material, elegant pattern and color. What the mixture of sex in man-woman is being shown highly can be found its factor attributable to sharing ambivalence along with the trend of a change in concept escaping from recognition of man and woman, and of the pursuit for functionality and convenience. The mixture of style showed the increasing trend with the mixture of style in the fixed form and non-fixed form in the traditional form of knit fashion. In the mixture of space, the traditional knit pattern in Northern Europe with long history in knit was being shown by being mixed with modern element. The mixture of time wasn't shown the mixture of science, which is expressed in the fabric clothing. The mixture of function showed characteristic of being available for a change in silhouette, by which over two items become one item according to situation and coordination or can be utilized as the use in two items. The mixture of other material showed characteristic of being utilized diverse materials by surpassing a range of the use in addition to functional use.

As the above, the characteristics in the mixed phenomena, which are shown in contemporary knit fashion, are being expanded gradually the range in the possibility for its expression by being added imagination owing to characteristic in colorful culture in multi-cultural era, and to the mixture of heterogenous element and other domain.

In conclusion, this study aims to have significance in suggesting its possibility as unique material with international competitiveness as the origin of creativity in mapping out and developing design in the field of knit fashion, and is expected to be likely to be possibly utilized as data necessary for establishing diverse theories academically.

\section{References}

Bainers, B. B. (1981). Fashion revivals, from Elizabethan age to the present day. London: B.T. Batsford.

Che, K. S. (1999). Fashion design practical affairs. Seoul: 
Kyung Choon Sa.

Cho, E. G. (2004). A study on the hybridity in contemporary art-Centeringon Craig Owens' view on postmodernismMaster's thesis, Hong Ik University, Seoul.

Cho, S. A. (2002). Fusion phenomena expressed in fashion. Master's thesis, Seoul National University, Seoul.

Debby, R. (1987). The encyclopedia of knitting techniques. Emmaus: Rodale Press.

Deborah, N. (1992). Designing knit wear. Newtown Conn: Taunton Press.

Jeon, H. O. (2001). A study on the evolution of knitwear. Master's thesis, Kunkuk University, Seoul.

Jong, S. M. (2006). A study on the hybrid trend of design hotel. Master's thesis, Yeonsei University, Seoul.

Kim, D. H. (2006). A study on mixed-media and hybrid objects in modern art. Ph. D.'s thesis, Dankook University, Seoul.

Kim, G. R. (2005). A study on expression of hybrid fashion and make-up in multi culturalism in fashion. Ph. D.'s thesis, Sungshin Women's University, Seoul.

Kim, K. H. (1995). Dictionary of popularity musical terms. Seoul: Arum.

Kim, K. I. (2008). Hybrid in contemporary hair design. $\mathrm{Ph}$. D.'s thesis, Kyung Hee University, Seoul.

Kim, M. J. (1998). A study modernism and post-modernism expressed on fashion 20th century: Focused on anti-aestetics, open-fashion. Journal of the Korean Society of Costume, 38, 369-392.
Kim, S. R. (2003). A study on fusion style presented in the Seoul Collection-Focus on '01 S/S '03 S/S fashion desisnger shows-. Master's thesis, Yonsei University, Seoul.

Kim, Y. I. (2007). Look, nine views of fashion. Seoul: Kyomunsa.

Lee, Y. M. (2001). A study on the design of fusion styles in fashion trend. Master's thesis, Chung-Ang University, Seoul.

Mendes, V. \& De La Haye, A (1999). 20th century fashion. London: Thames \& Hudson.

Myung, I. (2003). A comparative study on the design characteristics of Greg Lynn and Marcos Novak in hybrid inclination of digital architecture. Master's thesis, Dankook University, Seoul.

Oh, S. H. (2000). Study for fusion phenomena affected on the fashion design in the latter half of the 20th century. Master's thesis, Kookmin University, Seoul.

Park, S. H. (2005). A study on the fusion style in contemporary fashion design. Master's thesis, Hong Ik University, Seoul.

Shin, J. H. (2003). A study on the characteristics of hybrid in the contemporary architecture. Master's thesis, Seoul National University, Seoul.

Yu, K. Y. (2003). A study on the mixed imitation in modern fine art: Centering along my work. Master's thesis, Sungshin Women's University, Seoul.

\section{요 약}

현대사회의 혼합화 현상과 니트웨어의 수요 증가에 따른 독특한 질감이 요구되어지고 있어 이에 따른 전략적인 방안들이 절실히 요구되고 있다. 본 연구는 세계 4대 컬렉션의 2000 2008년의 여성컬렉션의 횡 편 니트 3 8게이지의 자료를 선정, 현대 니트패션에 나타난 혼합현상을 출현 빈도와 표현특성으로 분석 하였다. 혼합현상은 상 - 하위문화의 혼합, 남 - 여 성의 혼합, 스타일의 혼합, 공간의 혼합, 타소재의 혼합, 기능의 혼합의 순으로 나타났으며, 2004년에 가장 높은 빈도수를 나타냈다. 혼합현상의 표현특성에서 가 장 높은 빈도수를 나타낸 상 - 하위문화의 혼합은 고급스러운 소재, 고상한 무늬와 색상의 상 - 하위개념의 경계성의 모호와 남·여 성의 혼합은 기능성과 편리성의 추구와 양성성의 공유로 특성을 나타냈다. 스타일 의 혼합은 니트패션의 전통적인 형태에서 정형과 비정형의 스타일의 혼합으로 특성을 나타냈고, 공간의 혼합은 니트의 역사가 깊은 북유럽의 전통적 니트문양이 현대적인 요소와 혼합된 특성을 나타내고 있었 다. 타소재의 혼합은 장식적인 소재와 본래의 기능적인 용도를 초월하여 부분적으로 혼합되었고, 기능의 혼합은 두 가지 아이템의 용도로 활용 가능한 특성을 나타냈다. 이와 같이 현대 니트패션에 나타난 혼합 현상은 타영역의 혼합으로 상상력이 더해져 그 표현 가능성의 범위가 점차 확대되어 가고 있다. 